\title{
Direct versus indirect strategies for thyroid hormone reference intervals established in a middle-aged and elderly population on an immunoassay analyzer
}

\author{
Orta yaş ve yaşlı bir populasyonda immunoassay analizörle tiroid \\ hormon referans aralıkların belirlemek için direkt ve indirekt yöntemler
}

\author{
Sedat Motor, Gönül Erden, Birsen Sahillioğlu, Serpil Erdoğan, Mustafa Metin Yıldırımkaya \\ Ankara Numune Training and Research Hospital, Department of Clinical Biochemistry Ankara, Turkey
}

\begin{abstract}
Objectives: Establishment of reference values by direct strategy for selection of reference individuals is time-consuming and expensive for laboratories. The aim of this study was to establish reference intervals for thyrotrophin(TSH), free thyroxine (FT4), free triiodothyronine (FT3) in a middle-aged and elderly population (age range; 40-80 years) on an immunoassay analyzer using both direct and indirect strategies, and to compare the results of direct and indirect strategies.
\end{abstract}

Materials and methods: As for direct sampling strategy, healthy reference individuals were randomly selected (129 male, 131 female; age range: 40-80) by questionnaire. As for indirect sampling strategy, the results of TSH, FT3, FT4 measurements of all individuals (male, $n=3060-3920$; female, $n=4090-4520$; age range 40-80 years), were selected from laboratory information system. Reference intervals were calculated by nonparametric methods

Results: The following 95\% reference intervals were determined: For direct sampling group: TSH 0.32-4.38 $\mu \mathrm{lU} /$ $\mathrm{mL}$; FT4 0.75-1.32 ng/dL; FT3 1.98-3.65 pg/mL. For indirect sampling group: TSH 0.29-4.36 $\mu \mathrm{lU} / \mathrm{mL}$; FT4 0.71$1.37 \mathrm{ng} / \mathrm{dL}$; FT3 1.69-3.32 pg/mL. Indirect sampling group showed a good concordance in the reference intervals for TSH and FT4 with direct sampling group.

Conclusion: Indirect sampling strategy and nonparametric method may be confidently used to evaluate the reference intervals of serum TSH and FT4 on an analyzer. We suggested the utilization of a very simple and practical way, indirect sampling strategy, for evaluating reference intervals for elderly population. J Clin Exp Invest 2010; 1(3): 161-167

Key words: Direct method, indirect method, reference intervals, thyrotrophin, free thyroxine, free triiodothyronine.

\section{ÖZET}

Amaç: Referans bireylerden direkt yöntemle referans değerleri belirlemek her laboratuvar için hem zaman alıcı hem de maliyetli olmaktadır. Bu çalışmanın amacı, orta ve yaşlı populasyonun (yaş aralığı; 40-80 yaş) tirotropin (TSH), serbest tiroksin (ST4), serbest triiyodotironin (ST3) değerleri için Abbott Architect i2000 immunoassay analizöründe referans aralıklarını belirlemek ve indirekt ve direkt yöntem sonuçlarını birbiriyle karşılaştırmak.

Yöntem: Direkt yöntem için referans bireyler (129 erkek, 131 kadın; yaş aralığı: 40-80) anket formuyla seçildi. İndirekt yöntem için TSH, ST4, ST3 ölçüm sonuçları laboratuar bilgi sisteminden [erkek $\mathrm{n}=(3060-3920)$, kadın n=(4090-4520) yaş aralığı:40-80 yıl] elde edildi. Referans aralıklar nonparametrik metod ile hesaplandı.

Bulgular: \%95 merkezi alan temel alınarak referans araIıkları belirlendi. Direkt yöntem grubunda; TSH, 0.32-4.38 $\mu \mathrm{lU} / \mathrm{mL}$; ST4, 0.75-1.32 ng/dL; ST3, 1.98-3.65 pg/mL idi. İndirekt yöntem grubunda; TSH, 0.29-4.36 $\mu \mathrm{lU} / \mathrm{mL}$; ST4, 0.71-1.37 ng/dL; ST3, 1.69-3.32 pg/mL idi. İndirekt yöntem grubu TSH ve ST4 için direkt yöntem grubuyla çok iyi bir uyum gösterdi.

Sonuç: Indirekt yöntem ve nonparametrik metod Abbott Architect i2000 analizöründe TSH ve FT4 referans aralıkları belirlemede güvenli olarak kullanılabilir. Biz ilgilenilen bölgesel populasyonun referans aralıklarını belirlemek için indirekt yöntemle basit ve pratik bir yol öneriyoruz. Klin Den Ar Derg 2010; 1(3): 161-167

Anahtar kelimeler: Direkt yöntem, indirekt yöntem, referans aralık, tirotropin, serbest tiroksin, serbest triiyodotironin. 


\section{INTRODUCTION}

The purpose of reference values is to provide comparison data for the interpretation of patients' laboratory results. ${ }^{1}$ Reliable reference ranges are important in the interpretation of laboratory data. ${ }^{2}$ Establishment of reliable reference values is a major undertaking consisting of the selection of suitable reference individuals, preparation of these individuals for standardized sample collection, handling and analysis of the samples and statistical analysis and presentation of the results that are obtained. ${ }^{1}$ Several methods (direct/indirect; priori/posteriori; random/ non-random) have been suggested for the selection of reference individuals. Direct selection of reference individuals is the only method that agrees with the concept of reference values as recommended by the IFCC..$^{3-5}$ The disadvantages of the direct methods include the selection and clinical characterization of suitable populations for the establishments of reference values are time-consuming, and the mandatory measurement of high numbers of samples is expensive. ${ }^{6}$ Less expensive and simpler strategy is indirect sampling method. ${ }^{7,8}$

Reliable reference intervals are especially important for thyroid hormone assays because these tests are widely used in the screening, diagnosis, treatment and monitoring of thyroid disease. ${ }^{2}$ Population-specific reference intervals are of particular importance for thyroid hormones because recent literature highlights the fact that thyroid hormone reference intervals can differ considerably from country to country ${ }^{9}$ Reference intervals for FT4 and TSH varied considerably between populations as differences were reported among countries using the same Abbott Architect Immunoassay in 2 European and 1 Arabic population. ${ }^{2,9,10}$

Serum concentrations of the thyroid hormones show a clear age dependency. ${ }^{11}$ Kratzch et al indicated that patient age (for TSH, FT4, and FT3) ought to be considered as selection criteria for further reference interval studies in the diagnostic evaluation of thyroid diseases. ${ }^{6}$

Kratzsch et al reported that age was an independent factor that was significantly inversely associated with TSH and TSH concentrations of persons $<40$ years of age were significantly higher than concentrations in the group above 40 years of age. ${ }^{6}$ Hoogendoorn et al, reported that serum TSH decreases gradually with age, whereas serum free
T4 increases with age in individuals older than 60 years. $^{12}$

There have been several Turkish populationbased reference interval studies including age 18-40 years from different regions of Turkey. However, reference intervals of thyroid hormones for individuals older than 40 year old have not been evaluated so much.

The aim of this study was to establish reference intervals for TSH, FT3, FT4 in a middle-aged and elderly Turkish population (age range; 40-80 years) attending a training and research hospital using the Abbott Architect i2000 immunoassay analyzer, and to compare the results of estimations of reference intervals from direct and indirect sampling strategies.

\section{MATERIALS AND METHODS}

The study was undertaken at the major state (training and research) hospital of Turkey, in Ankara. All of the reference individuals were selected within 5 months of period.

As for direct sampling method, 260 apparently healthy adults, age between $40-80$ years old (130 male, 130 female), from well-person outpatient clinic were randomly included into the study (Individuals who are well and having no problem attend this clinic in order to investigate their health status). The nature and purpose of the study were explained to the subjects before their informed consent was obtained after approval of the study protocol by the local human ethics committee. All of them filled out a questionnaire requesting information concerning health status, a family history of thyroid diseases, smoking habits, diet, sufficient iodinated salt-intake, physical exercise, medications, and use of oral contraceptives. Questionnaire was prepared according to the NCCLS 28-A recommendations. The women who were pregnant or received oral contraceptive, individuals under hormone replacement therapy, individuals with known or newly diagnosed thyroid disease, individuals taking medication that may affect TSH, FT3, FT4 and individuals with acute or chronic illness, and obese individuals (Body Mass Index $>30 \mathrm{~kg} / \mathrm{m}^{2}$ ) were excluded form reference healthy group.

As for indirect sampling method, data obtained from laboratory information system were evaluated. The results of TSH, FT3, FT4 levels of all of the 
individuals (male, $n=3060-3920$; female $n=4090$ 4520), age between 40-80 years old, including all outpatients and hospitalized patients submitted to our laboratory in the same period were selected.

TSH, FT3 and FT4 levels were analyzed using Chemiluminescent Microparticle Immunoassay on the Abbott Architect i2000 immunoassay analyzer (Abbott Diagnostics Division, Abbott Laboratories, USA); the analyses were carried out according to the manufacturer's instructions. Third generation TSH assay was used. Minumun detection limits of TSH, FT3 and FT4 are $0,0025 \mu \mathrm{IU} / \mathrm{mL}, 1,0 \mathrm{pg} / \mathrm{mL}$ and $0,4 \mathrm{ng} / \mathrm{dL}$, respectively. Maximum detection limits of TSH, FT3 and FT4 are 100,000 $\mu \mathrm{IU} / \mathrm{mL}$, $30 \mathrm{pg} / \mathrm{mL}$ and $6 \mathrm{ng} / \mathrm{dL}$, respectively. Analytical imprecision was monitored by assaying 2 levels of lyophilized commercial quality control material daily for three analytes. Our immunoassay laboratory is a participant of Randox International Quality Assessment Scheme (RIQAS) immunoassay programme.

Serum samples were collected in BD vacutainer system tubes without a gel separator. Venipuncture was performed after an overnight fasting, between 8-11 a.m. in the antecubital vein of the subjects. The samples were allowed to clot before separation by centrifugation at $3000 \mathrm{xg}$ for 15 minutes.

The analytical performance reported covered a period of 6 months. Within-run imprecision (intraassay CV) for FT3, FT4 and TSH were 4.6\%, 4.57\% and $4.91 \%$, respectively. Day to day (interassay CV, 20 testing days) imprecision for FT3, FT4 and TSH were $6.4 \%, 7.3 \%$ and $5.01 \%$, respectively. The study was approved by the local ethics committee.

\section{Statistical analysis and estimation of reference intervals}

All data was entered into a data base and analyzed using SPSS for Windows 11.5. KolmogorovSmirnov test was used to assess normality of the data. 13 Where indicated, data was log transformed before analysis. The reference intervals were calculated as representing the $95 \%$ confidence intervals. In accordance with the National Committee for Clinical Laboratory Standards (NCCLS) ${ }^{14}$ protocol and the International Federation of Clinical Chemistry and Laboratory medicine (IFCC) ${ }^{13}$, the central $95 \%$ range between the 2.5 th and 97.5 th percentiles were taken to be the reference interval.
The manufacturer's kit inserts notice central 99\% reference intervals for FT4 and TSH. For comparison the $99 \%$ reference intervals were also calculated for the populations studied. The inter-percentile reference interval may be estimated using both parametric and nonparametric statistical methods. ${ }^{1}$ The nonparametric method for the recommendation 13 was the simple, rank-based procedure described by Reed et al. ${ }^{15}$ Only the nonparametric method has been recommended for general use. ${ }^{13}$ We estimated all of the reference values by using nonparametric methods.

Nonparametric methods (i) Order the reference values according to increasing value, (ii) assign rank numbers to these values, (iii) calculate the rank number of the alpha $(\alpha)$ percentile as $\alpha(n+1) / 100$, where $\mathrm{n}$ is the sample size, and (iv) look up (interpolate) the corresponding percentile values. ${ }^{13,15}$

The identification and elimination of outliers were done prior to estimation of reference values 1 .

For direct sampling: Dixon test, which identifies an extreme value as an outlier if the difference between the two highest (or lowest) values in the distribution exceeds one third of the range of all values, was used. ${ }^{13}$ For indirect sampling: SPSS for Windows v 11.5. analyze/ descriptive statistics/ explore step was used to exclude outliers. ${ }^{16}$

Among the indirect sampling group (data obtained from laboratory information system) FT3, FT4 and TSH did not have a normal distribution according to Kolmogorov-Smirnov test. TSH data, obtained from direct sampling group (reference healthy individuals), did not have a normal distribution according to Kolmogorov-Smirnov test. FT3 and FT4 data, obtained from reference healthy individuals, had normal distribution according to Kolmogorov-Smirnov test.

All TSH data was log transformed and the transformed ranges were used in the calculations followed by a reverse transformation to obtain the actual values for the reference interval. Statistical differences between the groups Mann-Whitney U, Student's t- tests were performed as needed. P values $<0.05$ were defined as statistically significant.

\section{RESULTS}

Calculated values for TSH, FT4 and FT3 by gender and age are shown in Table 1. Concerning gender, no significant difference in median free $\mathrm{T} 4$ was seen 
between males and females ( $p>0.05)$. However, median TSH and FT3 showed significant differences between males and females $(\mathrm{p}<0.05)$. Median TSH was higher (direct sampling group: $27 \%$; indirect sampling group 31\%) in females when compared to males in both sampling groups $(\mathrm{p}<0.05)$. Median FT3 was higher (direct sampling group: 5.2\%; indirect sampling group 3.1\%) in males when compared to females in both sampling groups $(\mathrm{p}<0.05)$.

Concerning age, no significant differences were found for TSH, FT3, FT4 values between two age (40-59 and 60-80) groups when direct sampling group was studied $(\mathrm{p}>0.05)$. Concerning age, significant differences were found for TSH, FT3 values between two age (40-59 and 60-80) groups, when indirect sampling group was studied $(\mathrm{p}<0.05)$. Lower (8.3\%) TSH and lower (\%5.3) FT3 values in older subjects were observed.
In Table 2, the reference intervals of the examined thyroid hormones, irrespective of gender and age, are reported as $95 \%$ and $99 \%$ reference intervals. Reference intervals given by the manufacturer are presented in Table 2. The calculated reference intervals, especially the upper limit values, of TSH and FT4 for direct sampling groups were similar to the calculated reference intervals of TSH, FT4 for indirect sampling groups (Table 1 and Table 2). Estimated 99\% reference intervals (except for the lower limit of TSH) for TSH and FT4 are in accordance with the $99 \%$ reference intervals given by the manufacturer. Direct sampling group did not show a good relevance in the reference intervals for FT3 with indirect sampling group. For FT3 the upper 99\% limit for direct sampling group was the same as the upper $95 \%$ limit given by the manufacturer.

Table 1. Values for TSH, free T4 and free T3 by gender and age

\begin{tabular}{|c|c|c|c|c|}
\hline & $\mathbf{n}$ & Direct sampling (Healthy subjects) & $\mathbf{n}$ & Indirect sampling (From LIS) \\
\hline \multicolumn{5}{|l|}{$\mathrm{TSH}, \mu \mathrm{IU} / \mathrm{mL}$} \\
\hline Males & 129 & $1.05(0.28-4.38)$ & 3920 & $1.06(0.27-4.29)$ \\
\hline Females & 131 & $1.34(0.40-4.40)$ & 4520 & $1.39(0.30-4.38)$ \\
\hline p-value & & 0.002 & & 0.001 \\
\hline $40-59$ years & 216 & $1.21(0.32-4.38)$ & 5630 & $1.30(0.31-4.35)$ \\
\hline $60-80$ years & 44 & $1.24(0.25-4.40)$ & 2810 & $1.20(0.26-4.38)$ \\
\hline p-value & & NS & & 0.001 \\
\hline \multicolumn{5}{|c|}{ Free $\mathrm{T} 4, \mathrm{ng} / \mathrm{dL}$} \\
\hline Males & 129 & $0.99(0.72-1.30)$ & 3890 & $1.01(0.71-1.35)$ \\
\hline Females & 131 & $1.00(0.71-1.40)$ & 4090 & $1.01(0.70-1.38)$ \\
\hline p-value & & NS & & NS \\
\hline $40-59$ years & 216 & $0.99(0.72-1.30)$ & 5320 & $1.00(0.71-1.33)$ \\
\hline $60-80$ years & 44 & $0.99(0.70-1.23)$ & 2660 & $1.03(0.70-1.40)$ \\
\hline p-value & & NS & & NS \\
\hline \multicolumn{5}{|c|}{ Free T3, pg/mL } \\
\hline Males & 129 & $2.82(1.99-3.72)$ & 3060 & $2.62(1.60-3.46)$ \\
\hline Females & 131 & $2.68(1.97-3.53)$ & 4455 & $2.54(1.71-3.27)$ \\
\hline$p$-value & & 0.009 & & 0.001 \\
\hline $40-59$ years & 216 & $2.78(1.97-3.61)$ & 5015 & $2.60(1.75-3.34)$ \\
\hline $60-80$ years & 44 & $2.60(2.00-3.72)$ & 2500 & $2.47(1.60-3.26)$ \\
\hline$p$-value & & NS & & 0.001 \\
\hline
\end{tabular}

Data reported represent the median value $\left(2.5^{\text {th }}-97.5^{\text {th }}\right.$ percentile). To study statistical difference between groups ( $p$ value) Mann-Whitney U, Student's t- tests were performed. NS=not significant, LIS=laboratory information system. Conversion to SI units: TSH: $\mathrm{mIU} / \mathrm{L}=\mu \mathrm{IU} / \mathrm{mL}$; fT4: $\mathrm{pmol} / \mathrm{L}=\mathrm{ng} / \mathrm{dLx} 12.87$; fT3:pmol/L=pg/mLx1.53. 
Table 2. Different methods' results of $95 \%$ and $99 \%$ reference intervals for TSH, FT4 and FT3 irrespective of gender and age

\begin{tabular}{lllll}
\hline & Central & TSH $\mu \mathrm{IU} / \mathrm{mL}$ & FT4 ng/dL & FT3 pg/mL \\
\hline Direct sampling & $\mathbf{9 5 \%}$ & $0.32-4.38$ & $0.75-1.32$ & $1.98-3.65$ \\
& $\mathbf{9 9 \%}$ & $0.25-4.77$ & $0.70-1.43$ & $1.84-3.71$ \\
Indirect sampling & $\mathbf{9 5 \%}$ & $0.29-4.36$ & $0.71-1.37$ & $1.69-3.32$ \\
& $\mathbf{9 9 \%}$ & $0.21-4.95$ & $0.61-1.44$ & $1.54-3.52$ \\
Manufacturer's & $\mathbf{9 5 \%}$ & - & - & $1.71-3.71$ \\
& $99 \%$ & $0.35-4.94$ & $0.70-1.48$ & - \\
\hline
\end{tabular}

Conversion to SI units: TSH: $\mathrm{mIU} / L=\mu \mathrm{IU} / \mathrm{mL}$; fT4: $\mathrm{pmol} / \mathrm{L}=\mathrm{ng} / \mathrm{dLx} 12.87 ; \mathrm{fT} 3: \mathrm{pmol} / \mathrm{L}=\mathrm{pg} / \mathrm{mLx} 1.53$.

Table 3. Published reference intervals of TSH, FT4 and FT3 for healthy reference populations as determined by the Architect analyzer

\begin{tabular}{|c|c|c|c|c|c|}
\hline & $\mathrm{n}$ & Age, years & $\mathrm{TSH} \mu \mathrm{IU} / \mathrm{mL}$ & FT4 ng/dL & FT3 pg/mL \\
\hline \multirow[t]{4}{*}{${ }^{*}$ Hoogendoorn et al. ${ }^{14}$} & & $18-$ & $0.34-4.66$ & - & - \\
\hline & 5156 & $45-49$ & $0.46-3.70$ & & \\
\hline & & $50-54$ & $0.36-4.45$ & & \\
\hline & & $55-59$ & $0.47-3.82$ & & \\
\hline Dhatt et al. ${ }^{11}$ & 742 & $16-75$ & $0.30-4.32$ & $0.76-1.45$ & - \\
\hline \multirow[t]{2}{*}{ Sagrado et al. ${ }^{2}$} & 100 & $17-84$ & $0.51-5.95$ & $0.84-1.42$ & $1.48-3.37$ \\
\hline & & $51-84$ & $0.38-6.61$ & $0.85-1.44$ & $1.39-3.14$ \\
\hline \multirow[t]{2}{*}{ Hubl et al. ${ }^{10}$} & 217 & $18-90$ & $0.17-4.23$ & 0.87-2.09 & $1.67-4.15$ \\
\hline & 42 & $51-90$ & $0.18-3.46$ & $0.94-2.17$ & $1.32-4.08$ \\
\hline \multirow[t]{2}{*}{ Present study } & 260 & $40-80$ & $0.32-4.38$ & $0.75-1.32$ & $1.98-3.65$ \\
\hline & 216 & $40-59$ & $0.32-4.38$ & $0.72-1.30$ & 1.97-3.61 \\
\hline
\end{tabular}

"Exclusion due to antibodies when selecting reference population

Conversion to SI units: TSH: $\mathrm{mIU} / \mathrm{L}=\mu \mathrm{lU} / \mathrm{mL} ; \mathrm{fT} 4: \mathrm{pmol} / \mathrm{L}=\mathrm{ng} / \mathrm{dLx} 12.87 ; \mathrm{fT} 3: \mathrm{pmol} / \mathrm{L}=\mathrm{pg} / \mathrm{mLx} 1.53$.

Table 4. Central $95 \%$ reference intervals calculated by nonparametric methods for reference healthy Turkish populations from different studies.

\begin{tabular}{llllll}
\hline & TSH $\mu \mathrm{lU} / \mathrm{mL}$ & FT4 $\mathrm{ng} / \mathrm{dL}$ & FT3 pg/mL & Age range, years* & Assay method \\
\hline Present study $(\mathrm{n}=260)$ & $0.32-4.38$ & $0.75-1.32$ & $1.98-3.65$ & $40-80$ & Chemiluminescent (Architect i2000) \\
Enli et al. ${ }^{16}(\mathrm{n}=259)$ & $0.30-4.17$ & $0.80-1.90$ & $1.3-4.4$ & $18-40$ & Chemiluminescent (Immulite one) \\
Ilcol and Aslan ${ }^{20}(\mathrm{n}=327)$ & $0.51-3.51$ & $0.86-1.66$ & $2.33-4.14$ & $18-40$ & Chemiluminescent (Advia-Centuar) \\
\hline
\end{tabular}

Conversion to SI units: TSH: $\mathrm{mIU} / \mathrm{L}=\mu \mathrm{IU} / \mathrm{mL} ; \mathrm{fT} 4: \mathrm{pmol} / \mathrm{L}=\mathrm{ng} / \mathrm{dLx} 12.87 ; \mathrm{fT} 3: \mathrm{pmol} / \mathrm{L}=\mathrm{pg} / \mathrm{mL} 1.53$.

* Healthy reference individuals selected by questionnaire 


\section{DISCUSSION}

Our data showed no significant changes in FT4 according to gender and age. These findings are similar to the data from Dhatt et al. ${ }^{10}$ However, these data are not similar to reports from Hubl et al. and d'Herbomez et al. They reported significant gender differences for FT4 concentrations; similar to our findings they did not report any consistent age-related differences. ${ }^{9}, 18$

Distributions of TSH values are in accordance with reported results 2, 9. Median TSH was higher (direct sampling group: $27 \%$; indirect sampling group $31 \%$ ) in females when compared to males in both sampling groups. This finding is similar to a study which found significantly higher TSH values in healthy females. ${ }^{2}$ The tendency of lower TSH concentrations in older subjects is similar to the findings of some studies for healthy, hospitalized and ambulatory patients. ${ }^{9,12,17}$

Studies from different populations vary widely according to used analytical methods, as well as inclusion and exclusion criteria. From a whole study group of healthy blood donors $(n=870)$, Kratzch et al. defined a constraint group (age range: 18-68 y; $\mathrm{n}=453$ ) exclusive of individuals with family history of thyroid disease, positive autoantibodies, increased FT4 and FT3, and sonographically assessed abnormalities of the thyroid. ${ }^{6}$ They measured serum concentrations of thyroid hormones on the ELECSYS system assays (Roche Diagnostics). Interestingly, only the calculated lower limit for TSH differed significantly from the constraint group. ${ }^{19}$

Our findings and some of the estimates of previous studies on Architect i2000 analyzer for thyroid hormones are given in Table 3. Marked differences between reference limits, from different studies, were accepted as $\pm 5 \%$ deviation from the compared limit. ${ }^{6}$

The $95 \%$ reference interval for FT4 estimated in this study, was considerably different from the other FT4 reference intervals reported from other countries. ${ }^{2,}, 1095 \%$ reference interval for TSH, irrespective of gender and age, estimated in this study was very similar to the study by Dhatt et al (Table $3)$. The upper limit calculated for TSH is similar to Hubl et al's study. In a population with borderline sufficient iodine intake, Hoogendoorn et al explored influences of age and sex. ${ }^{12}$ They reported that serum TSH gradually decreases with age. Our reference interval for 40-59 age group for TSH was similar to the 50-54 age group calculated by Hoogendoorn et al. (Table 3).

A study similar to our age group, evaluated the reference intervals for 40-60 years old $(\mathrm{n}=211)$ and $>70$ years old $(n=216)$ groups 11 . TSH was measured with IMx (microparticle enzyme immunoassay, Abbott Laboratories). They recommended that the reference intervals of serum TSH in older $(>70 \mathrm{y})$ individuals be considered to be the same as that healthy middle-aged (40-60) individuals. ${ }^{11}$ They found no difference between male and female groups. Our data are not in accordance with these observations reported by Hershman et al. ${ }^{13}$

Calculated reference intervals and assay methods from the other Turkish population specific studies are shown in Table 4. ${ }^{16,20}$ Their age range was different from this study. Findings of our age group were not similar to the reference intervals calculated for the younger population. However, it was observed that even in the same country for the same age group, the upper or the lower reference value might be different. These differences in reference intervals in different populations or laboratories may affect patient management.

Concerning age, a limitation for this study was the small number of the group for our elderly direct sampling group $(n=44)$. The data presented from direct sampling group is mostly representative of a healthy 40-59 years old Turkish population.

It is recommended that each laboratory define its own reference intervals. ${ }^{4,21}$ However, the establishment of reference values by using direct strategy for selection of reference individuals is time-consuming, and expensive. As a result, clinical laboratories frequently use only insufficiently approved reference intervals given by the manufacturers of commercially available assays. ${ }^{6}$ We suggest the utilization of a very simple and practical way, indirect sampling strategy, of evaluating reference intervals for the local population we deal with. It should be kept in mind that indirect method has several deficiencies.

It may be reported that indirect sampling strategy and nonparametric method may be confidently used to evaluate but not to establish the reference intervals. Laboratory results from large hospital databases are to be used as reference values only if the laboratory data can be combined with informa- 
tion stored in clinical databases. ${ }^{3}$ As a result of a very similar study to our study from Turkey, Ilcol and Aslan ${ }^{22}$ suggested that using this relatively easy technique, every laboratory can produce its own reference intervals, divided, where possible, according to sex and age and according to local conditions. These ranges can be complementary to reference intervals obtained for reference individuals according to the IFCC recommendations. ${ }^{22}$

Our data show that the $99 \%$ reference intervals for TSH and FT4 determined by the manufacturer on the Abbott Architect i2000 immunoassay analyzer can be recommended for use in Turkish population age 40-80 years old.

In conclusion, indirect sampling strategy and nonparametric method may be confidently used to evaluate the reference intervals of serum TSH and FT4 on Abbott Architect i2000 analyzer. Selected reference healthy individuals (direct sampling group) showed a good congruence in the reference intervals for TSH and FT4 with our unselected group (indirect sampling group) obtained from LIS. However, the lower and upper limits of the FT3 reference interval in the indirect sampling group were $>5 \%$ different from the comparable limit of the direct sampling group.

\section{REFERENCES}

1. Solberg HE. The IFCC recommendation on estimation of refernce intervals. The Referral Program. Clin Chem Lab Med 2004;42:710-4.

2. Gonzales-Sagrado M, Martin-Gil FJ. Population-specific reference values for thyroid hormones on the Abbott ARCHITECT i2000 analyzer. Clin Chem Lab Med. 2004;42:540-2.

3. Burtis CA, Ashwood ER, Bruns DE. Establishment and use of reference values.In: Solberg HE. Tietz Textbook of Clinical Chemistry and Molecular Diagnostics, fourth ed. Elsevier Saunders, 2005:425-448.

4. International Federation of Clinical Chemistry, Expert Panel on Theory of Reference Values.. Approved recommendation on the theory of reference values. Part 1 . The concept of reference values. J Clin Chem Clin Biochem 1987;25:337-42.

5. International Federation of Clinical Chemistry, Expert Panel on Theory of Reference Values. Approved recommendation on the theory of reference values. Part 2. Selection of individuals for the production of reference values. J Clin Chem Clin Biochem. 1987;25:639-44.

6. Solberg HE. International Federation of Clinical Chemistry, Expert Panel on Theory of Reference Values, and International Committee for standardization in Haematology, Standing Committee for reference values. Approved recommendation on the theory of reference values. Part 5.Statistical treatment of collected reference values. J Clin Chem Clin Biochem 1987; 25:645-56.

7. Kratzsch J, Fiedler GM, Leichtle A, et al. New reference intervals for thyrotropin and thyroid hormones based on National Academy of Clinical Biochemistry criteria and regular ultrasonography of the thyroid. Clin Che. 2005;51:1480-86.

8. Grasbeck R, Alström T. Reference values in laboratory medicine. The current state of the art. Chichester, England: John Wiley, 1981.

9. Baadenhuijsen H, Smit JC. Indirect estimation of clinical chemical reference intervals from total hospital patient data: Application of a modified Bhattacharya procedure. J Clin Chem Clin Biochem 1985;23:829-39.

10. Hubl W, Schmieder J, Gladrow E, Demant T. Reference intervals for thyroid hormones on the Architect analyzer. Clin Chem Lab Med 2002;40:165-6.

11. Dhatt GS, Griffin G, Agarwal MM. Thyroid hormone reference intervals in an ambulatory Arab population on the Abbott Architect i2000 immunoassay analyzer. Clin Chim Acta 2006; 364:226-9.

12. Zöphel K, Wunderlich G, Kotzerke J. Should we really determine a reference population for the definition of thyroid-stimulating hormone reference interval? Clin Chem 2006;52:329-30.

13. Hershman JM, Pekary AE, Berg L, Solomon DH, Sawin CT. Serum thyrotropin and thyroid hormone levels in elderly and middle-aged euthyroid persons. J Am Geriatr Soc 1993;41:823-8.

14. Hoogendoorn EH, Hermus AR, Vegt FD, et al. Thyroid function and prevalance of anti-thyroperoxidase antibodies in a population with borderline sufficient iodine intake: Influences of age and sex. Clin Chem 2006;52:104-11.

15. National Committee for Clinical Laboratory Standards. How to define and determine reference intervals in the clinical laboratory; approved guideline, 2nd ed.Villanova, PA. NCCLS; 2000. NCCLS Document C28-A2 (ISBN 1-56238-406-6)

16. Enli Y, Aslan D, Akalın N, et al. Determination of Reference intervals for 18-40 years old people living in Denizli by using different methods. Turk J Biochem 2003; 28;228-45.

17.Reed AH, Henry JR, Mason WB. Influence of statistical method used on the resulting estimate of normal range. Clin Chem 1971;17:275-84.

18. Davey R. Thyroxine, thyrotropin, and age in euthyroid hospital patient population. Clin Chem 1997;43:2143-8.

19. d'Herbomez M, Forzy G, Gasser F, Massart C, Beaudonnet A, Sapin R. Clinical evaluation of nine free thyroxine assays: persistent problems in particular populations. Clin Chem Lab Med 2003;41:942-7.

20. Ilcol Y, Aslan D. Determining reference value of blood chemistry profile in healthy subjects in Bursa. Turk J Biochem 2004;29:183-92.

21. National Committee for Clinical Laboratory Standards. How to define and determine reference intervals in the clinical laboratory; proposed guideline. 1995. NCCLS Document C28-A. Villanova, PA. NCCLS.

22. Ilcol YO, Aslan D. Use of total patient data for indirect estimation of reference intervals for 40 clinical chemical analytes in Turkey. Clin Chem Lab Med 2006;44:867-76. 